\title{
NEGARA DAN ILEGALITAS: STUDI KASUS PERDAGANGAN BURUNG DI WILAYAH JAKARTA
}

\author{
Indraini Hapsari $\left({ }^{1} *\right)$, Semiarto Aji Purwanto $\left({ }^{2}\right)$ \\ ${ }^{12}$ Department of Anthropology, Faculty of Social and Political Sciences, Universitas Indonesia, Jakarta, Indonesia.
}

\begin{tabular}{ll} 
ARTICLE INFORMATION \\
\hline Submitted & $: 25^{\text {th }}$ December, 2019 \\
Review & $: 06^{\text {th }}$ March, 2020 \\
Accepted & $: 30^{\text {th }}$ April, 2020 \\
Published & $: 1^{\text {st }}$ June, 2020 \\
Available Online & $:$ June, 2020
\end{tabular}

\section{KEYWORDS}

State; illegality; bird trade; center-periphery; Jakarta.

\section{CORRESPONDENCE}

*E-mail:indrainihapsari@gmail.com

\begin{abstract}
A B S T R A C T
This article aims to analyze the relationship between state and illegality which taking place at the center, namely in Jakarta. The study becomes significant for examining how mechanisms and relations of non-state and state actors occur. Many ethnographic studies of illegal activities, such as gold mining, logging, and fishing show that such businesses take place on the periphery or border where the state has weak control over such places. Data is conducted by literature study and short field observations. Our case studies of illegal trade in the bird market in Jakarta will question the Weberian perspective which defines the state as a legal and rational institution that will always enforce control in its territory. In this article, we consider the state as a relational arena where it is possible for various actors, both non-state and state actors, to participate in illegal activities through contestations or collaboration to achieve their respective interests or goals.
\end{abstract}

\section{A. PENDAHULUAN}

A ktivitas perdagangan satwa liar bukanlah sebuah fenomena yang baru. Menurut van Uhm (2016), sejak peradaban manusia yang paling awal, aktivitas perdagangan satwa hidup sudah terjadi, yakni mulai dari masa kekuasaan Firaun di Mesir sampai para kaum aristokrat di era modern ini. Ramses II sering terlihat bersama dengan peliharaannya berupa seekor singa dan Julius Caesar juga pernah menerima hadiah berupa seekor jerapah dari Cleopatra (2016:1). Hal ini menunjukkan bahwa sejak zaman awal peradaban manusia hingga dewasa ini, pasar untuk satwa, baik sebagai bahan makanan, bahan pakaian, peliharaan, atau objek hiburan sudah banyak diminati oleh kalangan-kalangan tertentu.

Berbicara mengenai pasar hewan, tidak lengkap bilamana tidak membahas mengenai pasar yang ada di kawasan Asia. Kawasan
Asia merupakan pusat perdagangan satwa liar yang dilindungi yang menjadi sumber, jalur transit, dan juga pasar hewan langka. Kawasan Asia Tenggara sendiri sudah dikenal sebagai pusat perdagangan satwa liar (wildlife trade). Indonesia yang memiliki biodiversitas yang tinggi menjadi sumber yang penting di dalam perdagangan gelap satwa liar yang dilindungi. Kepolisian menyebutkan kegiatan ilegal ini menduduki urutan ketiga kejahatan di Indonesia yang jumlahnya berada di bawah perdagangan narkotika dan terorisme (Tempo 2019: 26).

Pasar yang menjual satwa liar terbesar di Asia Tenggara terletak di Indonesia, tepatnya di kawasan ibu kota, Jakarta, yaitu Pasar Barito, Jatinegara, dan Pramuka (TRAFFIC 2015). Perdagangan satwa, baik yang legal maupun ilegal, terjadi di tiga pasar tersebut. Pasar Barito yang terletak di Jalan Barito, Jakarta Pusat, terdiri atas kurang/lebih 30 deretan kios yang secara khusus 
menjual burung dan hewan lainnya yang terletak di pinggir jalan. Pasar Jatinegara, Jakarta Timur, terdiri atas kurang/lebih 40 toko burung permanen yang terletak di kanan dan kiri jalan (Jalan Kemuning); dan tambahan beberapa pedagang burung dengan kios yang tidak permanen yang berjualan di depan kios permanen dan juga di tepian Jalan Matraman Raya. Pasar Pramuka yang telah beroperasi sejak tahun 1976 berdiri di atas gedung permanen yang terdiri atas empat lantai dengan ratusan kios yang didominasi oleh penjual burung dan juga perlengkapan burung, seperti makanan dan kandang. Selain menempati gedung utama, ada juga beberapa kios burung permanen yang terletak di sekitar gedung utama (TRAFFIC 2015).

Pemaparan mengenai aktivitas perdagangan satwa liar di atas memunculkan pertanyaan-pertanyaan penelitian. Apakah aktivitas ilegal selalu dikaitkan dengan negara yang memiliki kontrol yang lemah di dalamnya? Apakah dengan memasukkan kontrol negara yang lebih kuat di dalam aktivitas perdagangan satwa ilegal akan mengurangi atau menghilangkan jumlah aktivitas tersebut? Bagaimana dengan Indonesia sendiri sebagai salah satu negara yang dijadikan sumber penting di dalam perdagangan satwa liar, apakah ini menggambarkan sistem pemerintahan dan penegakan hukum yang lemah?. Tulisan ini bertujuan untuk menganalisis hubungan antara negara dan ilegalitas dalam melihat aktivitas perdagangan satwa liar yang terjadi di ibu kota negara dan pengawasan yang dilakukan oleh negara terhadap aktivitas tersebut.

\section{B. METODE PENELITIAN}

$\mathrm{D}$ ata di dalam artikel ini diperoleh dengan memanfaatkan studi berbagai literatur yang membahas mengenai ilegalitas yang terjadi di Indonesia. Selain melakukan studi literatur, untuk mendapatkan data mengenai praktik ilegalitas di wilayah center, penulis melakukan penelitian empirik dan pengamatan secara singkat. Penelitian empirik yang melihat relasi antara manusia dengan komunitasnya, manusia dengan sumber daya alam, serta manusia dengan hukum akan memperlihatkan non-obvious connections antara regulasi-regulasi tertentu dan bagaimana individu atau kelompok merespons regulasi tersebut (Teletsky 2017: 120). Penelitian pertama dilakukan dengan melakukan wawancara dengan pegiat yang ada di sebuah lembaga yang terkait dengan konservasi dan perdagangan komoditas burung pada bulan Agustus tahun 2019. Dalam penelitian yang kedua, penulis melakukan wawancara dan pengamatan singkat di sebuah pasar burung di Jakarta pada bulan April dan September 2019.
Kasus perdagangan burung ilegal di sebuah pasar burung di Jakarta dipilih karena selain berkaitan dengan komoditas burung (terutama kicau) yang tengah menjadi tren di kalangan pecinta burung di perkotaan, juga erat kaitannya dengan lokasi dari pasar tersebut. Lokasi penelitian dipilih karena beberapa alasan. Pertama, seperti yang telah dijelaskan sebelumnya, berdasarkan laporan yang dikeluarkan oleh TRAFFIC (2015), beberapa pasar hewan di Jakarta menjadi salah satu pasar yang menjual satwa liar terbesar di Asia Tenggara. Kedua, secara konseptual, lokasi tempat perdagangan burung ilegal yang berada di ibu kota membuat penulis memikirkan kembali mengenai konsep dan/atau teori mainstream mengenai state formation yang selama ini dipahami dengan menggunakan kerangka berpikir Weberian. Lokasi pasar yang berada di ibu kota juga dapat membongkar pernyataan yang selama ini mengatakan bahwa aktivitas ilegal terjadi di wilayah yang mana negara lemah kontrol terhadapnya (Ballard 1997; Tagliacozzo 2005; Erman 2008; Ford \& Lyons 2019).

\section{HASIL DAN PEMBAHASAN 1. Kajian Praktik llegalitas di Indonesia}

$\mathrm{B}$ eberapa literatur telah menginspirasi penulis dalam penulisan artikel dengan topik mengenai relasi antara negara dengan aktivitas perdagangan burung ilegal ini. Tinjauan terhadap literatur-literatur juga dapat membuat penulis menemukan relung yang dapat diisi atau diperkaya (novelty) dengan penelitian yang akan dilakukan.

Tulisan pertama datang dari Erman (2008) yang membahas mengenai relasi antara aktoraktor negara dan para penambang timah ilegal di Pulau Bangka. Fokus utama dari tulisan ini adalah melihat bagaimana suatu aktivitas ekonomi ilegal adalah bukan sekadar persoalan memberikan label sebagai transaksi yang terdaftar atau tidak, tetapi juga mengenai relasi kuasa di antara aktor negara dengan masyarakat dalam usaha untuk mendapatkan akses sumber daya timah. Erman (2008) juga menjelaskan mengenai alasan mengapa Pulau Bangka menjadi wilayah yang strategis untuk dilakukannya penyelundupan terhadap timah. Penyelundupan timah yang banyak terjadi di Bangka disebabkan oleh kondisi geografis Bangka yang strategis, yakni dikelilingi oleh lautan dan pulau-pulau kecil, serta dekat dengan pasar bebas di Singapura dan Penang (2008: 93). Dengan kata lain, di dalam konteks kasus yang dijelaskan oleh Erman (2008), pertam-bangan ilegal timah di Bangka dapat berlangsung dan berkelanjutan karena lokasinya yang dianggap strategis, yakni di wilayah yang 
dianggap jauh dari jangkauan negara dan berdekatan dengan pasar bebas.

Lemahnya pengawasan negara juga menjadi penyebab perdagangan macan tutul Sunda, Prionailurus javanensis, yang masih terus berlanjut hingga kini (Nijman, dkk. 2019). Pada kasus yang lain, Jepson, dkk. (2011) juga melaporkan lemahnya kapasitas negara untuk meregulasi, absennya organisasi korporat besar, serta tidak adanya budaya yang kuat untuk melakukan konservasi satwa liar dalam diri masyarakat menjadi faktor terbesar penghambat sulitnya melakukan konservasi burung-burung liar di Indonesia. Baik tulisan Nijman, dkk. (2019) maupun Jepson, dkk. (2011) membuat penulis kembali berefleksi, apakah aktivitas ilegal memang berkaitan dengan kontrol negara di periferi yang lemah. Studi Iskandar dan Iskandar (2015) mengenai kontes burung kicau di Bandung, Jawa Barat dan dampaknya terhadap konservasi burung di alam memberikan penulis gambaran lain mengenai keterkaitan antara aktivitas pemeliharaan, perdagangan, dan kontes burung dengan jumlah perburuan burung di alam. Mereka melihat bahwa aktivitas pemeliharaan burung, kontes burung, dan perdagangan burung yang justru terjadi di perkotaanlah yang mendorong perburuan burung yang tidak terkendali di pedesaan. Sayangnya, mereka tidak secara mendalam menguraikan bagaimana proses perdagangan burung liar di perkotaan dapat terjadi dan berkelanjutan.

\section{Temuan Empiris di Lapangan}

Selain mengulas beberapa literatur, penulis juga melakukan pengamatan singkat ke sebuah lembaga konservasi burung dan sebuah pasar burung untuk mendapatkan temuan empirik. Pada bulan Agustus 2019, penulis mengunjungi sebuah lembaga konservasi yang berfokus pada pelestarian burung-burung liar di Indonesia. Penulis berbincang dengan salah seorang pegiat di lembaga tersebut. Menurutnya, upaya konservasi burung langsung berkaitan dengan aktivitas pemeliharaan burung (bird keeping) dan juga kontes burung (bird contest).

"Belakangan ini, tren bird keeping dan contest jadi lebih popular lagi di Indonesia. Dulu, aktivitas memelihara burung lebih banyak dikaitkan dengan tradisi Jawa, kukila. Kalau kukila yang dipelihara cuma perkutut. Perkutut jadi lambang prestisenya laki-laki Jawa. Sekarang ini, alasan orang memelihara burung sudah mengalami pergeseran; jenis burung yang dipelihara juga lebih beragam. Hampir semua song bird sepertinya, ya. Selain bird keeping, sekarang kontes burung juga sudah banyak ditemukan di berbagai daerah di Indonesia. Burung yang dikonteskan juga sangat beragam jenisnya, terutama song bird.

Tren bird keeping dan bird contest tadi telah menyebabkan peningkatan perburuan burung di daerah-daerah pedesaan. Burung-burung tersebut juga banyak dijual di perkotaan, bahkan kota besar, seperti Jakarta. Saya pernah mengobrol dengan salah satu petinggi di kantor BKSDA, beliau bilang bahwa pasar itu bagaikan suatu etalase. Burung-burung yang dipajang di dalam sangkar yang dilihat oleh pembeli, itu cuma sebagian yang muncul di permukaan.Di balik itu, ada burung-burung khusus yang hanya dikeluarkan ke serious buyer saja."

(Catatan lapangan, 28 Agustus 2019)

Memelihara burung sangat popular dan sudah menjadi hobi banyak orang di Indonesia (lqbal 2015:132). Burung yang dipelihara kebanyakan merupakan burung hasil perdaga-ngan yang tidak teregulasi (karena burung yang diperdagangkan merupakan spesies yang dilindungi). Hal itu membuat beberapa spesies menjadi terancam punah, seperti murai hijau jawa (Cissa thalassina), bulbul berkepala jerami (Pycnonotus zeylanicus), dan kakatua jambul kuning (Cacatua sulphurea) (2015:132). Memelihara burung juga merupakan tradisi yang melekat pada kebudayaan orang Jawa, oleh sebab itu permintaan burung lokal paling banyak adalah dari daerah-daerah di Pulau Jawa (TRAFFIC, 2015). Bilamana dibandingkan dengan pemelihara satwa bukan-burung, rumah tangga yang memelihara burung liar (wild-caught birds) yang termasuk dalam tiga kategori konservasi (burung kicau lokal, burung beo lokal, dan burung kicau impor) rata-rata memiliki pendidikan yang lebih tinggi serta kondisi perekonomian yang lebih baik. Di sisi lain, rumah tangga yang memiliki burung yang memang sengaja diternakkan secara komersial rata-rata memiliki kondisi perekonomian yang baik pula namun tingkat pendidikannya tidak setinggi mereka yang memelihara burung-burung liar (Jepson dan Ladle 2005).

Pada bulan September 2019, penulis mengunjungi sebuah pasar burung di daerah Jakarta. Sejauh pengamatan penulis, burungburung yang dipajang di sana tidak ada yang masuk daftar red list atau dikategorikan sebagai endangered oleh IUCN ${ }^{1}$. Dari wawancara dengan

${ }^{1}$ IUCN (The International Union for the Conservation of Nature) Red List of Threatened Species (dikenal juga sebagai 
seorang pedagang pakan burung terungkap bahwa ada burung-burung tertentu yang memang sengaja tidak dipajang oleh penjual di pasar tersebut, salah satunya adalah jalak putih

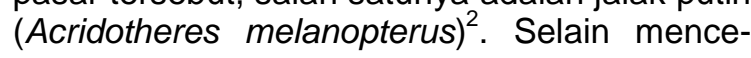
ritakan soal keberadaan burung-burung khusus tersebut, informan juga mengatakan bahwa petugas BKSDA (Balai Konservasi Sumber Daya Alam) yang bertugas di pasar tersebut jumlahnya sangat sedikit dan sangat jarang pula melakukan pengawasan. Informan juga mengatakan bahwa jaringan perdagangan burung ilegal yang terjadi di pasar tersebut juga diduga kuat melibatkan oknum aparatur negara.

\section{Negara Hukum yang Legal dan Rasional}

Setiap tahun, The World Justice Project $\left(\mathrm{WJP}^{3}\right)$, mengeluarkan sebuah peta dunia yang berisikan indeks peraturan hukum negaranegara di dunia. Tujuan mereka antara lain adalah mengevaluasi tingkat ketaatan warga negara pada peraturan. Indonesia menjadi salah satu negara yang diwakili oleh warna merah muda, yang menunjukkan tingkat ketaatan terhadap peraturan hukum rata-rata. WJP berupaya meningkatkan tingkat ketaatan negara-negara di dunia pada peraturan hukum karena mereka yakin bahwa hal itu dapat mengurangi angka korupsi, melawan kemiskinan dan penyakit, serta memproteksi masyarakat dari ketidakadilan. Peraturan hukum juga merupakan dasar dari keadilan, kesempatan, serta kedamaian di dalam masyarakat yang dapat menjadi penyokong pembangunan, pemerintahan yang akuntabel, serta penghargaan terhadap hak-hak fundamental manusia ${ }^{4}$. Dengan demikian, menurut WJP, tujuan dari kebijakan pembangunan adalah untuk memberikan stimulasi kepada negara-negara di dunia agar dapat melalui proses evolusi menuju indeks kuartil yang menunjukkan masyarakat yang lebih taat pada peraturan. McCarthy (2011: 92) mengatakan, "The governance discussion places the rule of

IUCN Red List atau Red Data List) dibentuk pada 1964 sebagai inventarisasi konservasi global yang menangani masalah spesies biologi. IUCN merupakan pemegang otoritas terbesar dunia yang berspesialisasi dalam menentukan status konservasi dari suatu spesies.

2 Jalak putih (Acridotheres melanopterus) termasuk salah satu burung yang dilindungi berdasarkan daftar lampiran yang dikeluarkan dalam PP No.7 Tahun 1999 tentang Pengawetan Jenis Tumbuhan dan Satwa serta tertuang dalam Undang-Undang No 5 Tahun 1994 ini dinyatakan berstatus kritis atau "critically endangered" oleh IUCN. (Sumber:http://www.satuharapan.com/read detail/read/jalak -putih-burung-endemik-berstatus-kritis)

${ }^{3}$ Dikutip dan disunting dari https://worldjustice project.org/rule-of-law-index/global (diakses pada 24 Mei 2019, pukul 10.11 WIB).

${ }^{4}$ Dikutip dan disunting dari https://worldjustice project.org/rule-of-law-index/global (diakses pada 24 Mei 2019, pukul 10.15 WIB).

4 | P a g e

https://doi.org/10.25077/ jantro.v22.n1.p1-9.2020 law' alongside democracy, a free press, and fair election as critical achievements of modernity." Kalimat ini, menurut penulis adalah awal bagi upaya untuk menjelaskan keterkaitan antara pemerintahan (governance) dan penegakan hukum di dalam lingkup pemerintahan itu sendiri.

Menurut Weber (1978: 217) tipe ideal dari dominasi terlegitimasi yang ditemukan di dalam masyarakat modern adalah otoritas yang legal dan rasional (rational grounds). Dalam rezim dominasi legal-rasional ini, setiap bagian dari hukum secara esensial berada di dalam sebuah sistem yang konsisten yang terdiri atas peraturan-peraturan yang abstrak yang dibuat secara sengaja. Bentuk dominasi yang legalrasional menjadi dasar negara modern. Weber juga mengatakan bahwa negara merupakan sebuah komunitas manusia yang (dengan sukses) mengklaim monopoli terhadap hak untuk menentukan apa yang legal dan ilegal di dalam teritorinya (Cribb 2011: 31). Pada negara-negara Barat, hukum tertulis dan keputusan pengadilan dianggap berasal dari masyarakat itu sendiri. Namun begitu, Moustaira (2017:304) mengatakan bahwa karakter mistik dan religius dari pondasi hukum sering kali diabaikan atau bahkan ditolak karena dianggap bertentangan dengan asumsi positivis yang legal dan juga rasional.

Dengan demikian, konsep dari legalitas sendiri sebenarnya inheren di dalam konsep modern mengenai negara. Negara dapat mendefinisikan apa yang legal atau ilegal dan menanamkan dasar perbedaan tersebut di dalam legitimasinya (Aspinall dan van Klinken 2011: 2). Aspinall dan van Klinken (2011) juga mentakan bahwa negara-negara yang tergabung di dalam Perserikatan Bangsa Bangsa (PBB) juga mengadopsi definisi negara Weber sebagai landasan legitimasinya, yakni bahwa negara memiliki kuasa untuk menegakkan hukum dan bila perlu menggunakan kekerasan untuk mencapai tujuan tersebut (2011: 2).

\section{Negara dan Paradoks Neoliberalisme}

Perdagangan satwa ilegal, selain membawa kerusakan pada lingkungan alam, juga membawa penulis pada pertanyaan mengenai posisi dan peran negara. Dari pernyataan McCarthy (2011: 90), "While state failure in environmental management contributes to environmental decline, it also brings up the very question of the state," penulis melanjutkan dengan pertanyaan, apakah kegagalan negara dalam mengatasi atau mengurangi jumlah aktivitas perdagangan satwa ilegal merupakan suatu gejala dari pemerintahan yang tidak baik? Apakah pemerintahan yang baik (good governance) ditandai dengan sistem negara yang kuat?

Sistem pemerintahan yang baik merupakan suatu kunci pemerintahan yang modern dan 
merupakan syarat yang krusial bagi demokrasi di era neoliberal. Secara global, neoliberalisme muncul sebagai rangkaian perubahan dan pergeseran di dalam ekonomi-politik dunia pada tahun 1970-an dan 1980-an (Nevins dan Peluso 2009: 9). Di Asia Tenggara sendiri, runtuhnya pemerintahan presiden Indonesia Soekarno yang menyebabkan dukungan Amerika Serikat dan Inggris pada masa Indonesia dalam krisis 1965-1966 dan perang Vietnam menjadi momen yang penting di dalam kemunculan neoliberalisme (2009: 9).

Merujuk pada von Mises yang menyatakan bahwa neoliberalisme merupakan kebangkitan ekonomi liberal laissez-faire di abad ke sembilan belas, Graeber (2015: 10) menyatakan bahwa gagasan mengenai pasar (harus) bertentangan dan independen dari pemerintah. Asumsi neoliberal atau ekonomi liberal laissezfaire di abad kesembilan belas tersebut yang menjadi titik tolak Graeber dalam melihat "sisi lain" asumsi tersebut. Alih-alih pasar bekerja secara lebih efisien tanpa campur tangan dari birokrasi pemerintahan, Graeber justru melihat adanya suatu paradoks di era neoliberal. Pengurangan campur tangan pemerintah di dalam proses ekonomi ternyata berakhir dengan diproduksinya regulasi, birokrasi, dan kebijakan yang lebih banyak (2015: 19).

Sejalan dengan itu, Nevins dan Peluso (2009) mengatakan bahwa karakteristik partikular dari negara-negara di Asia Tenggara yang otoritarian berpengaruh di dalam proses pembangunan pasca kolonialisme. Negaranegara otoritarian di Asia Tenggara telah memainkan peran yang penting di dalam menginisiasi, menjaga, dan memagari (enclosure) berbagai sumber daya alam, baik itu tanah, mineral, perikanan, yang ditujukan sebagai akumulasi swasta dan juga negara (2009: 3). Proses ini melibatkan apropriasi lahan, sumber daya, dan manusia, kemudian mengubah itu semua menjadi suatu komoditas agar akumulasi kapital dapat dilakukan (2009: 3). Merujuk pada Vandergeest dan Peluso (1995), proses tersebut juga dapat dikatakan sebagai teritorialisasi, yaitu "...the attempt by an individual or group to affect, influence, or control people, phenomena, and relationships by delimiting and asserting control over a geographic area" (1995: 388). Proses teritorialisasi dimaknai sebagai suatu proses yang dilakukan oleh negara modern untuk membagi wilayah menjadi zona-zona politik dan ekonomi yang kompleks serta saling tumpang tindih, mengatur kembali penduduk dan sumber daya dalam zona-zona tersebut, dan membuat aturan yang membatasi bagaimana dan oleh siapa wilayah tersebut dapat dimanfaatkan (Oktayanty 2014: 85).
Mencermati kasus perdagangan burung ilegal di atas dengan sistem pemerintahan di Asia Tenggara, khususnya Indonesia, maka pemerintah seharusnya menerapkan kontrolnya terhadap aktivitas tersebut. Pemerintah Indonesia telah menetapkan keanekaragaman hayati mana yang dianggap dilarang dan diperbolehkan untuk diperjualbelikan melalui Undang-Undang Nomor 5 Tahun 1990 tentang Konservasi Sumber Daya Alam Hayati dan Ekosistemnya serta regulasi turunannya, yakni Peraturan Menteri Lingkungan Hidup dan Kehutanan Nomor 20 Tahun 2018 tentang Jenis Tumbuhan dan Satwa yang Dilindungi. Dengan kata lain, pemerintah telah melakukan pemagaran (enclosure) (Nevins dan Peluso 2009) atau praktik teritorialisasi (Vandergeest dan Peluso 1995), dalam hal ini kepada jenis satwa tertentu. Penetapan status suatu satwa sebagai dilindungi atau dilarang diperjualbelikan telah menandakan bahwa negara memiliki kuasa dalam menerapkan kontrol dan manajemen terhadap sumberdaya alam yang ada di dalam teritorinya.

\section{Negara dan Praktik llegalitas}

Diskusi mengenai keterkaitan antara negara dan legalitas sebelumnya membawa penulis terhadap diskusi mengenai negara dan ilegalitas. Bilamana mendasarkan pemikiran menggunakan kerangka negaranya Weber, maka aktivitas yang dikatakan sebagai ilegal jelas dikatakan sebagai sesuatu yang tidak dapat diterima karena melanggar hukum dari negara. Ilegalitas dapat dikatakan sebagai efek dari negara karena melalui narasi dari ilegalitas tersebut, secara paradoksal kita dibawa untuk membayangkan aktor-aktor yang berada di dalam negara sebagai jawaban dari ilegalitas tersebut. Dengan kata lain, bilamana kita melihat aktivitas ilegal sebagai suatu bentuk pelanggaran hukum, maka jawaban dari hal itu adalah dengan memasukkan intervensi dan reformasi pemerintahan untuk menguatkan kapasitas negara dalam mengurangi ilegalitas tersebut (McCarthy 2011: 93). Selanjutnya, McCarthy (2011: 93) mempertanyakan, bilamana berpegang pada asumsi negara sebagai sebuah bentuk komunitas legal-formal seperti yang telah dijabarkan, mengapa kasus ilegalitas masih banyak terjadi?

Berenschot dan van Klinken (2018: 100) pernah mengatakan bahwa birokrasi di Indonesia tidak beroperasi sebagai sebuah institusi yang terikat pada peraturan, laiknya yang digambarkan oleh Weber di dalam mengaplikasikan hukum dan regulasinya. Di Indonesia, juga negara-negara lain di dunia, keterlibatan aktoraktor negara dalam aktivitas ilegal merupakan sesuatu yang sudah diketahui masyarakat umum dan tersebar di mana-mana (Aspinall dan van 
Klinken 2011: 2). Keterlibatan aktor-aktor negara di dalam aktivitas kriminal dalam suatu organisasi yang besar, seperti dalam pemerasan, penyelundupan, penebangan liar, dan perdagangan narkotika berdampak pada pandangan terhadap ilegalitas yang sering kali dilihat sebagai sesuatu yang terlegitimasi oleh sebagian masyarakat (2011: 4). Dengan demikian, aktivitas ilegal yang dilakukan oleh aktor-aktor negara akan lebih baik dipahami bukan sebagai suatu penyimpangan dari cara kerja negara yang normal, melainkan sebagai bagian dari logika negara itu sendiri (Aspinall dan van Klinken 2011: 19).

Alih-alih menggunakan kerangka berpikir negara yang diajukan oleh Weber, McCarthy (2011) menyarankan agar kita bisa memilih pendekatan lain yang memungkinkan untuk membongkar oposisi antara legal dan ilegal, serta memberikan perhatian terhadap ketidakcocokan antara logika hukum negara dengan praktik sehari-hari masyarakat. Pendekatan tersebut harus menunjukkan peran dari ilegalitas di dalam konteks yang lebih luas, di mana ilegalitas tersebut menjadi bagian dari logika dasar dari relasi politik yang sebenarnya dapat menyokong relasi tersebut (2011: 94). Pendekatan teori sosial terhadap negara dan hukumnya mengisyaratkan bahwa hukum sendiri merupakan refleksi dari suatu relasi kuasa (2011: 94). Sebelumnya, Heyman dan Smart (1999) juga sudah menekankan bahwa hukum (negara) telah menciptakan zona-zona ambiguitas dan ilegalitas itu sendiri. Studi empiris mengenai negara dan ilegalitas memungkinkan untuk melampaui asumsi yang mengatakan bahwa negara selalu menegakkan hukum di dalam teritorinya (1999: 1).

Aspinall dan van Klinken (2011) menawarkan sebuah pendekatan, yakni relasionalstrategis (strategic-relational approach) untuk mempelajari keterlibatan aktor-aktor negara di dalam suatu aktivitas ilegal yang banyak terjadi di Indonesia. Pendekatan ini melihat bahwa aktivitas ilegal yang dilakukan oleh aktor negara akan lebih baik dipahami sebagai sebuah produk dari strategi kompetitif di antara kepentingan-kepentingan dan aktor-aktor yang heterogen yang berada dalam negara (2011: 10). Pendekatan ini sebenarnya merupakan nomenklatur alternatif yang berasal dari pendekatan yang dibunyikan oleh Migdal (2001), yakni pendekatan state-in-society. Keduanya menekankan bahwa negara bukan merupakan suatu 'objek', melainkan sebuah arena relasional.

Seperti telah dijelaskan dalam pemaparan mengenai pendekatan relasional-strategis dan state-in-society di atas, studi mengenai negara kini harus dimasukkan ke dalam studi mengenai masyarakat. Ahli antropologi, ilmuwan politik, dan lainnya harus bisa lebih peka dalam melihat aktor-aktor negara yang berkolaborasi dengan masyarakat pada umumnya, sering kali sampai pada titik di mana batas yang memisahkan antara negara dengan masyarakat menjadi kabur atau bahkan terhapus, terutama pada level lokal (Aspinall dan van Klinken 2011: 12).

Banyak ilmuwan dan aktivis yang memahami istilah "ilegal" sebagai label yang diasosiasikan dengan hal yang negatif. Di dalam konteks tulisan ini, penulis sepakat dengan pandangan Thomas dan Galemba (2013) yang memahami "ilegalitas" sebagai sebuah kategori sosial, subjektif, politis, dan spasial yang diproduksi (2013: 211). Bilamana menyitir dari pernyataan Nicholas De Genova (2004), "There is [often] nothing matter-of-fact about illegality." Label legal atau ilegal menggambarkan sebuah relasi antara aktivitas perdagangan dengan suatu hukum negara (Bruns dan Miggelbrink 2012: 11). Dengan kata lain, baik perdagangan yang legal maupun ilegal merupakan dampak dari regulasi yang dibuat oleh negara.

Di dalam kasus perdagangan satwa ilegal di Indonesia, bila melihatnya hanya sebagai bentuk pelanggaran hukum yang bisa diatasi dengan kontrol negara, maka itu akan mengaburkan persoalan penting lainnya. Indonesia, tepatnya di kawasan Jakarta, adalah tempat di mana pasar yang menjual hewan liar terbesar di Asia Tenggara berada. Pasar-pasar tersebut tergolong sebagai pasar resmi yang mengantongi surat izin dari pemerintah setempat. Terletak di ibu kota, seharusnya negara memiliki kontrol penuh terhadap aktivitas yang terjadi di dalamnya. Namun demikian, perdagangan satwa ilegal masih dilakukan. Apakah kita masih bisa mengatakan bahwa negara yang lemah kontrol menjadi alasan utama berlangsungnya aktivitas perdagangan satwa ilegal di dalam pasar-pasar resmi tersebut? Dengan demikian, aktivitasaktivitas ilegal, dalam hal ini adalah perdagangan satwa ilegal yang terjadi adalah bukan sertamerta menggambarkan bentuk pelanggaran hukum (McCarthy 2011). Aktor-aktor negara yang terindikasi terlibat di dalam aktivitas ilegal tersebut, bukan juga merupakan bentuk penyimpangan dari cara kerja negara yang normal (Aspinall dan van Klinken 2011). Aktivitas perdagangan satwa ilegal, baik yang melibatkan aktor negara atau tidak, yang terjadi di dalam teritori sebuah negara merupakan epitome dari negara itu sendiri. Negara bukanlah sebuah entitas ideologis tetap yang berdiri di sebuah ruang hampa, tetapi merupakan sebuah arena relasional tempat berbagai tekanan sosial berkelindan satu sama lain melalui material atau simbol-simbol, saling berkompetisi memperebutkan supremasi melalui perjuangan dan akomodasi, pertentangan, dan koalisi (Migdal 2001: 107). 


\section{Menguji Praktik llegalitas di Wilayah Center}

Penulis belajar dari Tagliacozzo (2005: 5) mengenai undertrading, yaitu pergerakan contraband dalam jumlah yang besar atau, "the passage of goods underneath, or at the legal and geographic interstices of, the majority of items being traded in this arena". Undertrading biasanya berlangsung di tiga tempat, yakni di perbatasan atau wilayah periferi yang jauh dari pandangan dan jangkauan negara; di natural choke point seperti jalan setapak menuju wilayah pegunungan atau jalan air yang sempit, tempat yang biasanya tidak dilewati jalur perdagangan karena wilayah geografis yang sulit dilalui; dan di dalam hiruk-pikuk perkotaan tempat negara disibukkan dengan aktivitasaktivitas lain yang berjalan bersamaan (2005: 5).

Perdagangan burung ilegal yang dilakukan di ibu kota membuat penulis berefleksi terhadap tulisan tersebut. Pasar burung terbesar di Jakarta bukan berada di wilayah perbatasan atau periferi yang jauh dari pandangan dan jangkauan negara. Tidak juga di natural choke point. Apakah aktivitas perdagangan burung ilegal di Jakarta disebabkan karena "negara terlalu sibuk dengan aktivitas-aktivitas lain yang berjalan bersamaan"? Beberapa literatur yang menjelaskan masalah aktivitas ilegal, seperti pertambangan liar, penangkapan ikan ilegal, dan penebangan hutan liar biasanya dilakukan di dua tempat ideal yang disebutkan oleh Tagliacozzo (2005) di atas, yakni wilayah periferi atau natural choke point. Selain mempersoalkan masalah the nature of the state sebagai sebuah institusi legal-rasional yang selalu menegakkan hukum di dalam teritorinya, penulis juga akan memunculkan pertanyaan mengenai jaringan dari perdagangan burung ilegal yang terjadi di wilayah center tersebut.

Rademacher (2015) mengatakan bahwa studi etnografi yang terkait dengan ekologi politik sebagian besar dilakukan di wilayah pedesaan atau agraris (2015: 140). Sekarang, kita juga harus memberikan perhatian tentang bagaimana pusat institusi dan kuasa negara memengaruhi relasi-relasi kuasa yang ada di wilayah pedesaan atau pinggiran (2015: 140). Studi mengenai pusat institusi dan kuasa negara tersebut memberikan pemahaman etnografis yang lebih mendalam mengenai mekanisme birokrasi yang mendorong dan mengorganisasikan diskursus-diskursus perubahan lingkungan (2015: 140). Perdagangan burung ilegal di wilayah yang dianggap lebih dekat dengan pusat pemerintahan membuat penulis memikirkan kembali mengenai kompleksitas mata rantai jaringan perdagangan di dalamnya. Van Schendel dan Abraham
(2005) mengatakan bahwa penglihatan negara yang astigmatik terhadap wilayah zomia (wilayah yang jauh dari kontrol negara) akan berimplikasi pada negara yang selalu paranoid terhadap kondisi yang obscure tersebut. Biasanya, kegelisahan atau paranoia negara terhadap halhal tersebut digambarkan melalui proses pengamanan yang ketat (2005: 23).

Bilamana van Schendel dan Abraham (2005) mengatakan bahwa negara memiliki paranoia terhadap wilayah periferi sehingga ia cenderung terobsesi untuk menguatkan kontrol di wilayah tersebut, Ballard (1997) mengatakan hal sebaliknya. $\mathrm{Di}$ dalam komunitas lokal yang terletak di wilayah-wilayah frontier yang jauh dari pusat pemerintahan yang terdapat di AsiaPasifik, Afrika, dan Amerika Selatan, klaim negara terhadap pengawasan dan penguasaan sumber daya alam, terutama sumber daya mineral, kerap kali dilihat secara skeptis atau bahkan ditolak keberadaannya. Hal tersebut disebabkan karena absennya keberadaan negara di dalam wilayah-wilayah tersebut. Lebih jauh, ia mengatakan bahwa ketika kehadiran institusi negara hanya sedikit atau bahkan absen sama sekali, baik secara material maupun simbolis, di wilayah yang jauh dari pusat pemerintahan, kemampuan negara untuk menegakkan kedaulatan atau suaranya di wilayah-wilayah tersebut menjadi dipertanyakan kembali (Ballard dan Banks 2003: 296). Ford dan Lyons (2019) juga mengatakan bahwa mempelajari ilegalitas adalah hal yang penting di dalam konteks Indonesia. Mereka mengatakan bahwa aktivitas-aktivitas ilegal yang paling menyolok mata terjadi di wilayah periferi di mana agensi-agensi pemerintah sering kali kesulitan untuk mengawasi praktik-praktik ilegal yang muncul. Bagi Miswanto dan Arfa (2016:4), salah satu faktor yang mendorong terjadinya ilegalitas adalah karena kondisi geografis Indonesia yang luas sehingga menyulitkan aparat negara untuk memberantas aktivitas tersebut (2016: 4)

Dari pernyataan van Schendel dan Abraham (2005), Ballard (1997), serta Ford dan Lyons (2019) mengenai kehadiran negara dan pengaruhnya di wilayah periferi, penulis mengindikasikan kemungkinan terjadinya praktik ilegalitas yang melibatkan aktor negara di dalam-nya. Data dan analisis penulis menunjukkan bahwa terjadinya praktik ilegal di wilayah yang dekat dengan pusat pemerintahan dimungkinkan terjadi karena adanya jalinan para aktor, baik aktor nonnegara maupun negara, yang terlibat di dalam jaringan perdagangan komoditas ilegal tertentu. Perdagangan barang gelap tidak terjadi di wilayah antah-berantah atau ruang hampa, tetapi terjadi di suatu teritori yang dinamakan sebagai negara. Kontrol terhadap suatu teritori secara intrinsik berhubungan dengan karakte-ristik normatif dari negara modern yang berhak 
memonopoli kekerasan yang terlegitimasi untuk menegakkan hukum. Untuk bermain dengan rapi, mata rantai jaringan perdagangan ilegal di perkotaan mengisyaratkan rangkaian yang lebih panjang dan melibatkan lebih banyak aktor yang heterogen di dalamnya.

\section{KESIMPULAN}

$\mathrm{P}$ raktik ilegalitas terjadi di berbagai wilayah di Indonesia, terutama di wilayah periferi atau frontier. Wilayah tersebut potensial sebagai lokasi terjadinya praktik ilegalitas karena negara dianggap sering kali memiliki kontrol yang lemah di dalamnya. Studi mengenai perdagangan burung ilegal di sebuah pasar burung di Jakarta ini menunjukkan bahwa praktik ilegalitas juga berlangsung di wilayah center, yakni lokus yang sering diasumsikan bahwa negara memiliki kuasa yang kuat di dalamnya. Dari perspektif negara Weberian, praktik ilegalitas di wilayah center dan keterlibatan aktor negara merupakan penyimpangan dari negara sebagai institusi legal dan rasional. Akan tetapi, sebagaimana diungkap Aspinall dan van Klinken (2011) serta McCarthy (2011), praktik ilegalitas tersebut merupakan bagian yang membangun logika negara itu sendiri. Dengan melihat negara sebagai sebuah arena kekuasaan (Migdal 2001; Aspinall dan van Klinken 2011), dapat dipahami bahwa lokus terjadinya praktik ilegalitas merupakan sebuah arena yang di dalamnya terdapat berbagai aktor, yang berinteraksi satu sama lain untuk mencapai kepentingan masing-masing, baik sendiri-sendiri atau bersama.

\section{E. UCAPAN TERIMA KASIH}

U capan terima kasih penulis sampaikan kepada Irwan Hidayana dan Suraya Afiff dari Program Pasca Sarjana, Departemen Antropologi, Universitas Indonesia atas fasilitasi dan diskusi selama penulisan artikel. Terima kasih juga diucapkan kepada semua pihak yang telah berkontribusi, baik secara materiil maupun moril, dalam proses penulisan artikel ini yang tidak dapat penulis sebutkan satu per satu.

\section{DAFTAR PUSTAKA}

Aspinall, E., \& G. Van Klinken. (2011). The State and Illegality in Indonesia. Aspinall, E., \& G. Van Klinken (eds.) The State and Illegality in Indonesia. Leiden: KITLV Press.

Ballards, C., \& G. Banks. (2003). Resource Wars: The Anthropology of Mining. Annual Review Anthropology, 32(-), pp. 287-313.

Berenschot, W.,\& G. Van Klinken. (2018). Informality and Citizenship: The everyday state in Indonesia. Citizenship Studies, 22(2), pp. 95-111.

Bruns, B., \& J. Miggelbrink. (2012). Subverting Borders: Doing Research on Smuggling and SmallScale Trade. Wiesbaden: VS Verlag.

Cribb, R. (2011). A system of exemptions: Historicizing state illegality in Indonesia. Aspinall, E. \& G. Van Klinken (eds.) The State and Illegality in Indonesia. Leiden: KITLV Press.

De Genova, N. (2004). The Legal Production of Mexican/Migrant "Illegality". Latino Studies 2, pp. 160185.

Erman, E. (2008). Rethinking Legal and Illegal Economy: A case study of tin mining in Bangka Island, pp. 91-111.

Ford, M., \& L. Lyons. (2019). The Illegal as Mundane: Researching border-crossing practices in Indonesia's Riau Islands. Routledge, pp. 1-16.

Heyman, J.M., \& A. Smart. (1999). States and Illegal Practices: An Overview. Heyman, J.M. (ed.) States and Illegal Practices. Oxford and New York: Berg.

Iskandar, J., \& B.S. Iskandar. (2015). Pemanfaatan Aneka Ragam Burung dalam Kontes Burung Kicau dan Dampaknya terhadap Konservasi Burung di Alam: Studi kasus di Kota Bandung, Jawa Barat. PROS SEM NAS MASY BIODIV INDON, 1(4), pp. 747-752.

Iqbal, M. (2015). Looking at Online Bird Trading in Indonesia: A Case Study from South Sumatra. Birding ASIA, 24(-), pp. 132-135.

Jepson, P., dkk. (2011). Assessing market-based conservation governance approaches: a socioeconomic profile of Indonesian markets for wild birds. Flora \& Fauna Internasional, Oryx, 45(4), pp. $482-491$. 
Jepson, P., \& R.J. Ladle. (2005). Bird-Keeping in Indonesia: Conservation impacts and the potential for substitution-based conservation responses. Oryx, 39(4), pp. 1-6.

McCarthy, J.F. (2011). The limits of illegality: State, governance, and resource control in Indonesia. Aspinall, E. \& G. Van Klinken (eds.) The State and Illegality in Indonesia. Leiden: KITLV Press.

Migdal, J. (2001). State in Society: Studying how states and societies transform and constitute one another. Cambridge: Cambridge University Press.

Miswanto \& Arfa, D. (2016). Perdagangan dan Penyelundupan Pekerja Migran Indonesia di Malaysia.Jurnal Antropologi: Isu-isu Sosial Budaya, 18(1), pp. 1-11.

Moustaira, E.N. (2017). Narratives of Laws, Narratives of Peoples.Nafziger, J.A.R. (ed.) Comparative Law and Anthropology. Glos, UK: Edward Edgar Publishing Limited

Nevins, J., \& N.L. Peluso. (2009). Taking Southeast Asia to Market: Commodities, nature, and people in the neoliberal age. Selangor, Malaysia: Strategic Information and Research Development Centre (SIRD).

Nijman, V., dkk. (2019). Dynamics of illegal wildlife trade in Indonesian markets over two decades, illustrated by trade in Sunda Leopard Cats. Biodiversity Conservacy International, pp. 1-14.

Oktayanty, Y. (2014). Dari Hutan Adat Kalawa ke Hutan Desa: Sebuah Teritorialisasi Negara Berbasis Masyarakat. Jurnal Antropologi: Isu-isu Sosial Budaya 16(1), pp. 83-97.

Tagliacozzo, E. (2005). Secret Trades, Porous Borders: Rademacher, A. (2015). Urban Political Ecology. Annual Review of Anthropology, 44(-), pp. 137-152.

Satu Harapan. (2016). Jalak Putih, Burung Endemik Berstatus Kritis. Available online from: http://www.satuharapan.com/read-detail/read/jalak-putih-burung-endemik-berstatus-kritis (Accessed May 24, 2019).

Teletsky, A. (2017). Legal Pluralism: Linking Law and Culture in Natural Resource Co-Management and Environmental Compliance. Nafziger, J.A.R. (ed.) Comparative Law and Anthropology. Glos, UK: Edward Edgar Publishing Limited.

Tempo (Majalah). (2019). Satwa llegal Taman Safari: Lembaga konservasi terbesar di Indonesia diduga terlibat dalam perdagangan ilegal hewan dilindungi (edisi 8-14 April 2019).

Thomas, K., \& Galemba, R.B. (2013). Illegal Anthropology: An Introduction. PoLAR: Political and Legal Anthropology Review, 36(2), pp. 211-214.

Traffic Report. (2015). In the Market for Extinction: An inventory of Jakarta's bird markets. Selangor (September 2015).

Vandergeest, P.,\& N. Peluso. (1995). Territorialization and the State Power in Thailand.Theory and Society, 24(3), pp. 385-426.

Van Schendel, W., \& I. Abraham. (2005). Illicit Flows and Criminal Things: States, Borders and the Other Side of Globalization. Bloomington, IN: Indiana University Press.

Van Uhm, D.P. (2016). The Illegal Wildlife Trade: Inside the World of Poachers, Smugglers and Traders. Switzerland: Springer International Publishing.

Weber, M. (1978). Economy and Society: An outline of interpretive sociology. Berkeley: University of California Press.

World Justice Project. (2019). WJP Rule of Law Index. Available online from: https://worldjusticeproject.org/rule-of-law-index/global (Accessed May 24, 2019). 